\title{
Agro Morphological Characterization and Evaluation of Three Okra [Abelmoschus esculentus (L.) Moench] Varieties from Zinder (Niger) for Yield and Other Variability Components
}

\author{
Rabiou Abdou1, Oumarou Zango', Abdoul Karim Toudou², Timothée Kouassi Agbo So ${ }^{2 *}$, \\ Yacoubou Bakasso ${ }^{2}$
}

${ }^{1}$ Department of Biology, Faculty of Sciences and Techniques, Université de Zinder, Zinder, Niger

${ }^{2}$ Department of Biology, Faculty of Sciences and Techniques, Université Abdou-Moumouni, Niamey, Niger

Email: *kagboso@gmail.com

How to cite this paper: Abdou, R., Zango, O., Toudou, A.K., Agbo So, T.K. and Bakasso, Y. (2022) Agro Morphological Characterization and Evaluation of Three Okra [Abelmoschus esculentus (L.) Moench] Varieties from Zinder (Niger) for Yield and Other Variability Components. Agricultural Sciences, 13, 321-329.

https://doi.org/10.4236/as.2022.133022

Received: January 27, 2022

Accepted: March 5, 2022

Published: March 8, 2022

Copyright () 2022 by author(s) and Scientific Research Publishing Inc. This work is licensed under the Creative Commons Attribution International License (CC BY 4.0).

http://creativecommons.org/licenses/by/4.0/ (c) (i) Open Access

\begin{abstract}
Okra, (Abelmoschus esculentus (L.) Moench), is grown as a sole crop and as a field crop in Niger. In the present study, three okra varieties from Zinder region in Niger Republic have been assessed for their agronomic performance traits. The experiment was conducted in a randomized complete block design with three replications during the dry season 2018-2019. The following characters were evaluated: emergence; germination; boutonization flowering; fructificaion; height at flowering; height at maturity; length of the petiole; diameter of leaves; diameter of plants; number of fruits; number of fruit per branch; total number of fruits; number of branch, number of leaves; length of fruits; diameter of fruits; number of arrets; weight of fruits; weight of seed, number of seeds. The collected data were subjected to analysis of variance (ANOVA) using XlStat version 7.1 and the means separated by using Turkey's Method. Analysis of Principal components (PCA) using R software was also performed on the variables. There were significant differences for all characters except emergence, germination, diameter of plants, number of fruits, total number of fruits and diameter of fruits. The multivariate analysis by the ACP showed a grouping of the varieties in three groups. The three okra varieties have revealed good performances and could be useful for a breeding program. The study of the water needs of the varieties will be very interesting to make a better selection of the collection.
\end{abstract}




\section{Keywords}

Agronomic Performance, Okra, Abelmoschus esculentus (L.) Moench, Multivariate Analysis, Niger Republic

\section{Introduction}

Okra, (Abelmoschus esculentus (L.) Moench), is an exceptional and original plant because all its parts are valued on the food, medicinal, artisanal and even industrial levels. Indeed, it is among the vegetables, a plant providing products with nutritional value even exceeding that of the tomato [1] [2]. Its high levels of carbohydrates, proteins, vitamins $\mathrm{A}$ and $\mathrm{C}$, iron, phosphorus, potassium and magnesium have been demonstrated by [3] [4] and [5]. According to [6], the young fruits of okra contain mucilage with various properties of dispersion stabilizers, blood plasma substitute, thinner of liquid and blood systems. Roasted okra seeds are used in parts of Nigeria as a coffee substitute [7].

In Niger, okra is grown as a sole crop and as a field crop, in association or in juxtaposition with a main annual crop (millet, sorghum, maize) [8]. Paradoxically, it has always been a marginalized culture and generally reserved for women. This may be due to ignorance of the virtues of the plant and the fact that the country's improvement programs have not paid particular attention to this providential plant (MAE, 2019) [9]. Despite this socio-economic interest, very little information relating to the agronomic and morphological evaluation of okra from Niger is available and the research carried out so far has most often been limited to incomplete inventories.

Since 2018, the University of Zinder (UZ) has undertaken collection and evaluation activities of cultivated okra from the Zinder Region in Niger. These activities are based on the collection of local cultivars, agronomic and morphological characterization with a view to designing and implementing a selection and genetic improvement program for okra in the Zinder region.

This study aims to promote a better understanding of the morphological and agronomic diversity of Okra in the Zinder region. Precisely, it is a question of describing the genetic diversity collected by using the parameters which discriminate the different varieties and the structuring of the collection.

\section{Materials and Methods}

The present study was carried out on 3 varieties of okra (Abelmoschus esculentus (L.) Moench), collected from producers in the Zinder region (Figure 1). The experiment was laid out in a randomized complete block design with 3 replications at the research farm of the Department of Biology, Faculty of Sciences and Techniques, University of Zinder (Niger Republic) during the rainy season 2018-2019. The local soil is classified as sandy clay. Uniform cloves of each morphotype were planted during the middle of September for the season 2018-2019. 


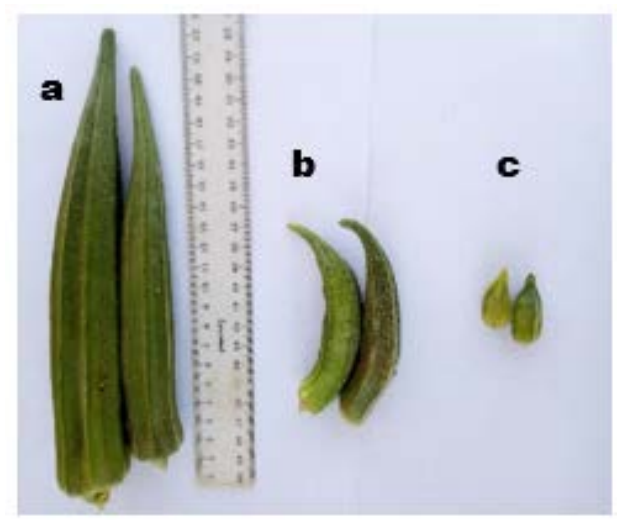

Figure 1. Fruits of the three okra varieties. a: Long $(4.4 \mathrm{~cm})$; b: Medium $(7.0 \mathrm{~cm})$; c: Short $(9.9 \mathrm{~cm})$.

Four seeds were sown and thinned to one plant per hill when plants reached 4 5 leaves stage. Each plot consisted of $5 \mathrm{~m}$ long and $4 \mathrm{~m}$ wide, with a spacing of $0.75 \mathrm{~m} \times 0.75 \mathrm{~m}$. Two consecutive blocks were separated by a $1 \mathrm{~m}$ driveway, while two consecutive plots were $0.5 \mathrm{~m}$ apart. Weeds were removed by hand every 2 weeks. Before sowing, we carried out spreading of $2 \mathrm{~kg} / \mathrm{m}^{2}$ of decomposed organic matter and an addition of $5 \mathrm{~g} / \mathrm{m}^{2}$ of mineral fertilizer NPK 15-15-15, then urea was brought to 30 days after sowing at a rate $5 \mathrm{~g} / \mathrm{m}^{2}$. Five plants were randomly selected and marked from each morphotype in each plot ignoring those on the peripheries.

The data were recorded on the middle plants. 12 plants were used for analysis by adapting [10] which was also used by [11] to assess Niger onion. The following characters were evaluated: Emergence (Emg); Germination (Ger); Boutonisation $(\mathrm{Bu})$ Flowering (Flo); Fructificaion (Fruc); Height at flowering ( $\mathrm{HFl}$ ); Height at maturity (HMa); Lenght of the petiole (Lpe); Diameter of leaves (DL); Diameter of plants (Dia); Number of fruits (NFr); Number of fruit per branch (NFrBr); Total number of fruits (TNfr); Number of branch (NBr); Number of leaves (Nle); Lenght of fruits (LFr); Diameter of fruits: (DFr); Number of arret (Nar); Weight of fruits (WFr); Weight of seed (Wse), Number of seeds: (Nse).

\section{Results and Discussion}

\section{Performance of Varieties}

Analysis of the performance of the varieties reveals the existence of inter-variety variability (Table 1 ). The different okra varieties differ significantly for all characters except Emergence (Emg), Germination (Ger), diameter of plants (DTg), Numbero fruits (NFr), Total number of fruits (TNFr) and Diameter of fruits (DFr) (Table 1). Okra varieties emerged in less than 6 days. These observations are contrary to those made by [12] in central Ethiopia which indicate a significant difference for the date of emergence. The varieties of okra used have a flowering period which varies 39 to 78 days after sowing. This date is early compared to that obtained by Eshiet \& Brisibe [13] who highlighted a flowering date 
of 71 to 112 days on okra varieties from Nigeria. This difference between the results would be linked to the difference in the cycles of the varieties and to the effect of the environment. Indeed, according to [14], prolonged exposure to drought of okra plants accelerated flowering in the plant. The flowering intervened between 47.65 days (long variety) and 61.76 days (short variety). These results are close to those recorded by [15]. These authors cited a variation of 36 to 68 days in 36 varieties of okra from Pakistan. Plant height at flowering ( $\mathrm{HFl}$ ) and maturity (HMa) of okra varieties range from 13.83 to $30.11 \mathrm{~cm}$ and 23.26 to $57.39 \mathrm{~cm}$ respectively. The long variety is the one with the best scores for these characters. It is also the one with the highest fruit length (LFr) and weight of fruits (PFr) with $15.20 \mathrm{~cm}$ and $12.58 \mathrm{~g}$ respectively. This performance of the variety could be explained by an excellent genetic potential. Similar observations were made by [16] which obtained fruit length values close $(14.8 \mathrm{~cm})$ to those reached in this present work. The greatest variation was observed for the number of seeds (Nse). The standard deviation for this trait is 29.3 (Table 1). This testifies to the existence of a strong heterogeneity of okra varieties for this trait.

Table 1. Performance of varieties.

\begin{tabular}{|c|c|c|c|c|c|c|c|}
\hline & Means & $\mathrm{SD}$ & Min & Max & CV (\%) & $\operatorname{Pr}>F$ & Significant \\
\hline Emg & 5.79 & 0.71 & 5 & 8 & 12.42 & 0.002 & $* *$ \\
\hline Ger & 85.66 & 22.82 & 0 & 100 & 26.64 & 0.412 & ns \\
\hline $\mathrm{Bu}$ & 35.93 & 7.40 & 29 & 62 & 20.61 & 0.000 & $* * *$ \\
\hline Flo & 50.5 & 8.72 & 39 & 78 & 17.28 & 0.000 & $* * *$ \\
\hline Fruc & 51.54 & 8.80 & 40 & 79 & 17.09 & 0.000 & $* * *$ \\
\hline $\mathrm{HFl}$ & 22.64 & 10.34 & 4.8 & 56 & 45.68 & 0.000 & $* * *$ \\
\hline HMa & 40 & 21.01 & 6.4 & 98 & 52.53 & 0.000 & $* * *$ \\
\hline Lpe & 22.13 & 9.33 & 9.33 & 96.86 & 42.17 & 0.000 & $* * *$ \\
\hline $\mathrm{DL}$ & 17.90 & 5.23 & 6.83 & 31.33 & 29.22 & 0.000 & $* * *$ \\
\hline Dia & 11.76 & 12.63 & 4 & 170 & 107.41 & 0.12 & ns \\
\hline $\mathrm{NFr}$ & 3.48 & 1.36 & 0 & 8 & 39.03 & 0.059 & ns \\
\hline $\mathrm{NFrBr}$ & 0.56 & 1.19 & 0 & 5 & 211.94 & 0.000 & $* * *$ \\
\hline TNfr & 4.05 & 1.93 & 0 & 10 & 47.83 & 0.160 & $\mathrm{~ns}$ \\
\hline $\mathrm{NBr}$ & 1.45 & 1.77 & 0 & 7 & 121.88 & 0.000 & $* * *$ \\
\hline Nle & 15.69 & 3.85 & 8 & 26 & 24.55 & 0.000 & $* * *$ \\
\hline $\mathrm{LFr}$ & 10.39 & 5.39 & 2.53 & 23.83 & 51.85 & 0.000 & $* * *$ \\
\hline DFr & 2.48 & 0.60 & 0.1 & 3.8 & 24.22 & 0.180 & ns \\
\hline Nar & 6.82 & 1.23 & 5 & 9.66 & 18.12 & 0.000 & $* * *$ \\
\hline WPr & 10.20 & 3.45 & 4.26 & 20.7 & 33.88 & 0.000 & $* * *$ \\
\hline Wse & 7.501 & 3.551 & 1.8 & 18.233 & 47.34 & 0.000 & $* * *$ \\
\hline Nse & 99.15 & 29.32 & 46.33 & 240.33 & 29.57 & 0.000 & $* * *$ \\
\hline
\end{tabular}




\section{Grouping of Okra Varieties by the ACP}

\subsection{Contribution of Variables to Main Components}

The principal component analysis (PCA) made it possible to perceive the projection of the different variables in a two-dimensional graph. The results of the PCA on the contribution of the different variables to the formation of the axes are summarized in the table. The total variability within the varieties is expressed at $67.2 \%$ by the first 4 axes (Figure 2). This is lower with the results obtained by [17] and [12] with respectively a total variability of $80.45 \%$ and $71.33 \%$. The total variability of this study is greater than that obtained by [18] who highlighted a total variability of $64.32 \%$. Variability within varieties is explained on the basis of the two principal components (Axis 1 and 2). These two axes explain $52.9 \%$ of the variability. Indeed, axis 1 represents $40.6 \%$; as for axis 2, it explains $12.3 \%$ (Table 2). Axis 1 highlights the links between the variables Number of seeds, Length of fruits and height of the plant at maturity. Indeed, the length of the fruits $(89.8 \%)$ is the variables that explain better axis 1 by their positions. It is followed by the number of seeds variable $(89.7 \%)$, the grain weight variable (89.4\%) and the height of the plant at maturity (87\%). This axis reflects on the one hand the level of development of the plants and on the other hand the quality

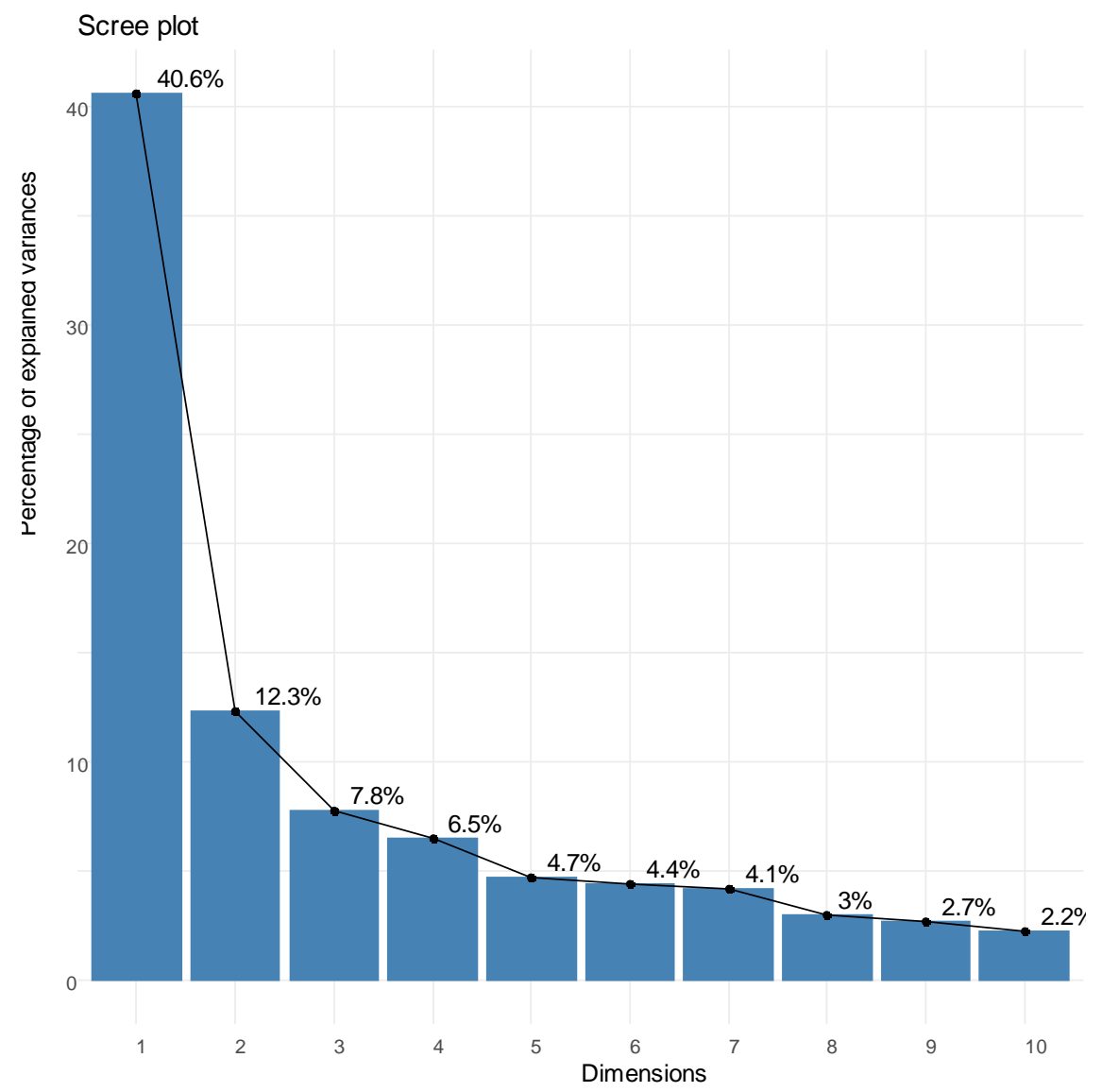

Figure 2. Variability of different axis. 
Table 2. PCA summary.

\begin{tabular}{|c|c|c|}
\hline & $\mathrm{F} 1$ & $\mathrm{~F} 2$ \\
\hline & Contributions (\%) & Contributions (\%) \\
\hline Emg & 20.98699439 & -11.9967041 \\
\hline Ger & 7.809021499 & -0.91056039 \\
\hline $\mathrm{Bu}$ & -59.10864509 & -29.8618859 \\
\hline Flo & -60.41103821 & -48.1881106 \\
\hline Fruc & -60.1461664 & -46.1064154 \\
\hline $\mathrm{HFl}$ & 82.12082164 & 6.25874439 \\
\hline $\mathrm{HMa}$ & 87.3275886 & 7.43947553 \\
\hline Lpe & 78.41573563 & -6.04082648 \\
\hline DL & 86.56153077 & -7.06645246 \\
\hline Dia & -1.519112298 & 35.5068191 \\
\hline NFr & 42.99718069 & 60.7857964 \\
\hline $\mathrm{NFrBr}$ & -29.57543032 & 77.602597 \\
\hline TNfr & 11.60003285 & 91.0774671 \\
\hline $\mathrm{NBr}$ & 80.57626613 & -5.1761259 \\
\hline Nle & -65.26803734 & 40.8260878 \\
\hline LFr & 79.50626368 & 9.26047131 \\
\hline DFr & 89.85810219 & -6.04513213 \\
\hline Nar & 7.440852328 & -20.5624852 \\
\hline WPr & 62.83315944 & -18.6966526 \\
\hline Wse & 76.37717803 & -17.6101609 \\
\hline Nse & 89.43965492 & -15.5476369 \\
\hline
\end{tabular}

of the fruits (Figure 3). Indeed, [19] obtained positive correlations between plant height at maturity and number of seeds. The second axis describes $13.3 \%$ of the variability. It groups, according to the importance of their contributions, the characters Total number of fruit, Number of fruits, Number of fruit per branch (Table 2). The Total number of fruits variable explains better the axis by its contribution of $91 \%$, followed by the number of fruits per branch $(77.6 \%)$ and the variable Number of fruits (60.7\%). This axis expresses the productivity criterion. Indeed, in general, the Number of fruit is a variable that is evaluated as a component of yield [20].

\subsection{Grouping of Varieties}

The observation of the layout of the varieties in plan of the ACP (Figure 4) allowed obtaining a grouping of varieties. Similarly, through the contribution of the variables that define the axes and the position of the varieties with respect to the axes, it is possible to define three groups as follows (Figure 3 ). 


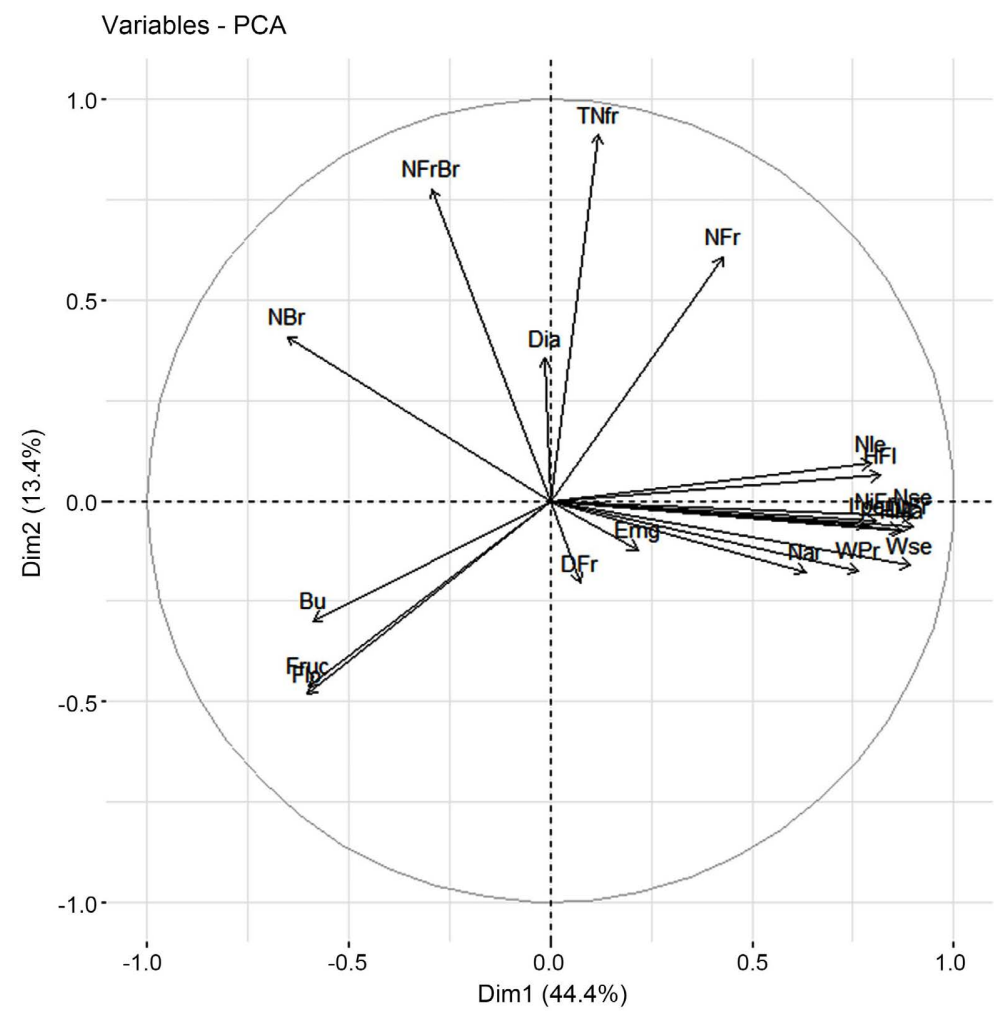

Figure 3. Contribution of variables to main components.

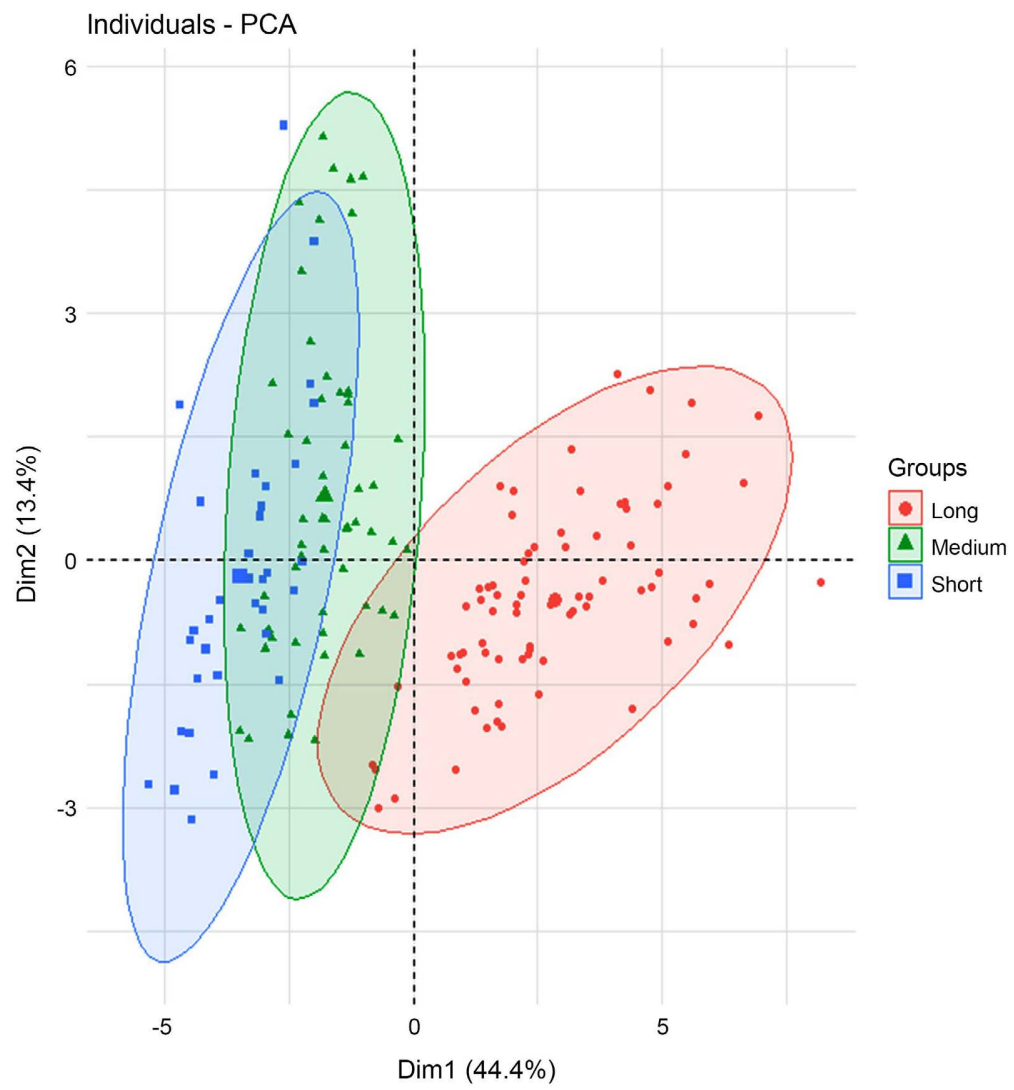

Figure 4. Contribution of variables to main components. 
Group 1 brings together individuals with a height of plants below the mean of individuals in the collection.

Group 2 includes individuals with a high number of fruits and a height of the plant at maturity equal to the average of all the individuals.

Group 3 includes individuals with a plant height at maturity and a length of fruits higher than the average of the other individuals.

\section{Conclusion}

Based on the present results, the research concluded that the okra varieties studied can be differentiated from one another depending on the height of the plant, length of fruits, and number of fruits. Therefore, the analysis of our collection revealed no significant differences only for emergence, germination, and diameter of plants, number of fruits, total number of fruits and diameter of fruits. The okra varieties had shown good performances and could be useful for a breeding program. It will be interesting to conduct the study of the water needs of varieties to make a better selection of the collection.

\section{Acknowledgements}

The research work has been done with the financial support of World Food Program (WFP) for financial and logistic support, and OUSSEINI ABDOU MAMAN Tassiou, LACHO AMADOU Haboubacar, ABDOULAYE MAMADOUMI Mahamadou, HACHIMOU ATTIKOU Mahamane Djamilou, IDRISSA YAHAYA Massaoudou for their participation to the collection and morphological characterization of Zinder okra.

\section{Conflicts of Interest}

The authors declare no conflicts of interest regarding the publication of this paper.

\section{References}

[1] Hamon, S. and Charrier, A. (1997) Les gombos. L'amélioration des Plantes Tropicales. Coédition CIRAD-ORSTOM, France.

[2] Sawadogo, M., Ouedraogo, J.T., Balma, D., Ouedraogo, M., Gowda, B.S., Botanga, C. and Timko, M.P. (2009) The Use of Cross Species SSR Primers to Study Genetic Diversity of Okra from Burkina Faso. African Journal of Biotechnology, 8, 2476-2482.

[3] Hamon, S. (1989) Etude de la variabilité génétique des espèces cultivées et des espèces spontanées du genre Abelmosehus (Gombo) non originaires d'Afrique de l'Ouest. ORSTOM. IBPGR, $84 \mathrm{p}$.

[4] Koechlin, J. (1989) Les gombos africains (Abelmoschus spp.): Etude de la diversité en vue de l'amélioration. Thèse de Doctorat, Paris-Grignon, Paris, $180 \mathrm{p}$.

[5] Nzikou, J.M., Mvoula, T., Matouba, E., Ouamba, J.M., Kapseu, C., Parmentier, M. and Desobry, S. (2006) A Study on Gumbo Seed Grown in Congo Brazzaville for Its Food and Industrial Applications. African Journal of Biotechnology, 24, 2469-2475.

[6] Marius, C., Gerard, V. and Antoine, G. (1997) Le gombo, Abelmosehus eseulentus 
(L.) Moench une source possible de phospholipides. Agronomie et Biotechnologies, Oléagineux, corps gras, lipides, 5, 389-392.

[7] Siemonsma, J.S. and Hamon, S. (2004) Abelmoschus esculentus (L.) Moench. In: Res-sources végétales de I Afrique Tropicale 2, Fondation PROTA, Wageningen, Pays-Bas, 25-30.

[8] MAE (Ministère de l'Agriculture et de l'Elevage) (2020) Rapport d'évaluation de la campagne agricole d'hivernage 2019 et Perspectives Alimentaires 2019/2020. 47 p.

[9] MAE (Ministère de l'Agriculture et de l'Elevage) (2019). Rapport d'évaluation de la campagne agricole d'hivernage 2019 et Perspectives Alimentaires 2018/2019. 45 p.

[10] IPGRI (2001) International Plant Genetic Resources Institute. Descriptors of Allium Spp. Rome.

[11] Abdou, R., Malice, M., Bakasso, Y., Saadou, M. and Baudoin, J.P. (2015) Variabilité morphologique et agronomique des écotypes d'oignon (Allium cepa L.) identifiés par les producteurs du Niger. Tropicultura, 33, 3-18.

[12] Temam, N., Mohamed, W. and Aklilu, S. (2020) Agro Morphological Characterization and Evaluation of Okra [Abelmoschus esculentus (L.) Moench] Genotypes for Yield and Other Variability Components at Melkassa, Central Ethiopia. MOJ Ecology \& Environmental Sciences, 5, 80-87. https://doi.org/10.15406/mojes.2020.05.00179

[13] Eshiet, A.J. and Brisibe, E.A. (2014) Morphological Characterization and Yield Traits Analysis in Some Selected Varieties of Okra (Abelmoschus esculentus L. Moench). Advances in Crop Science and Technology, 3, 5.

[14] Aziafekey, M., Odah, K. and Atayi, A. (2013) Effet de différentes modalités de stress hydrique sur la production et la teneur en éléments minéraux du gombo [Abelmoschus esculentus (L.) Moench]. International Journal of Biological and Chemical Sciences, 7, 1515-1523. https://doi.org/10.4314/ijbcs.v7i4.8

[15] Ali, A.S., Shah, H., Gul, R., Ahmad, H., Nangyal, H. and Sherwani, K.S. (2014) Morpho-Agronomic Characterization of Okra (Abelmuscus esculentus L.). World Applied. Sciences Journal, 31, 336-340.

[16] Saleem, A.M., Amjad, M., Ziaf, K. and Sahi, S.T. (2018) Characterization of Okra (Abelmoschus esculentus) Genotypes for Fruit Firmness, Other Horticultural Traits and Heritability Studies. International Journal of Agriculture and Biology, 20, 345-352. https://doi.org/10.17957/IJAB/15.0497

[17] Sharma, R.K. and Prasad, K. (2010) Characterisation of Promising Okra Genotypes on the Basis of Principal Component Analysis. The Society for Advancement of Hor ticulture, 12, 71-74. https://doi.org/10.37855/jah.2010.v12i01.16

[18] Nwangburuka, C.C., Kehinde, O.B., Ojo, D.K., Denton, O.A. and Popoola, A.R. (2011) Morphological Classification of Genetic Diversity in Cultivated Okra, $A b$ elmoschus esculentus (L) Moench Using Principal Component Analysis (PCA) and Single Linkage Cluster Analysis (SLCA). African Journal of Biotechnology, 54, 11165-11172. https://doi.org/10.5897/AJB11.285

[19] Komolafe, R.J., Ariyo, O.J. and Alake, C.O. (2021) Diversity in Phenotypic Traits and Mineral Elements of Okra (Abelmoschus esculentus L. Moench) Genotypes. International Journal of Agronomy, 2021, Article ID: 5528703.

https://doi.org/10.1155/2021/5528703

[20] Fondio, L., Kouamé, C.N.G., Traoré, D. and Djidji, A.H. (1999) Densité de semis, croissance et production de deux lignées de gombo ("Abelmoschus spp.") en Côte d'Ivoire. Cahiers Agricultures, 8, 413-415. 